\title{
Ukrainian Surnames in -enko
}

\section{YAR SLAVUTYCH}

$T_{H}$

HE SUFFIX -ENKO has generally been considered the most common onomastic formant in Ukrainian. Since it is not found in any other Slavic language it has been called a typical Ukrainian feature. Those people with surnames in -enko scattered throughout Siberia and the Soviet Far East are undoubtedly of Ukrainian descent: under the Russian tsars, and especially under Stalin's terrible rule, Ukrainians were deported en masse to these territories for labor.

The origin of the suffix -enko dates back to the second half of the twelfth century, ${ }^{1}$ when the reduced vowels $\breve{u}$ and $\breve{\imath}$ had already disappeared.2 Morphologically, the formant -enko consists of two suffixes: $-e n$ and $-k o(<\breve{u} k+o)$. The suffix -en denotes children and the young of animals: *děten, 'child,'*telen, 'calf,' while - $k$ - suggests diminutiveness. The final $-o$ is an ending. Consequently, -enko indicates 'son of,' a name for children "after one of their parents."3 Thus, the gradual development of the surname may be summarized as follows: Ivan $>$ Ivan-en-ja ( $<$ *Ivan-en-e 'young, little Ivan' < *Ivan-en-en) $>$ Ivan-en-ko $>$ Ivanenko," which means 'Ivan's son.'

The surname in -enko was first recorded in 1480 (poslaly esmo dvoranyna našoho Sen'ka Polozenka, "we have sent our nobleman Sen'ko Polozenko"). ${ }^{5}$ It is very probable that legal deeds of the time might reveal some older recording of this type.

1 O. B. Tkačenko, "Ukrajins'ki prizvyšča z sufiksom -enko ... (pytannja poxodžennja)," Slovjans'ke movoznavstvo, II, Kyjiv: Vydavnyctvo Akademiji Nauk Ukrajins'koji RSR, 1958, p. 52.

2 A. A. Šaxmatov, "Očerk drevnejšego perioda istoriji russkogo jazyka," Encyklopedija slavjanskoj filologiji, II, Petrograd, 1915, p. 228-229.

3 O. B. Tkačenko, ibid., p. 52.

4 Jacob P. Hursky, "The Origin of Patronymic Surnames in Ukrainian," The Annals of the Ukrainian Academy of Arts and Sciences in the United States, 1960, Vol. VIII, No. 1-2 (25-26), p. 177.

5 L. L. Humec'ka, her review of Slovjanske movoznavstvo, II in Ukrajins'ka mova $v$ školi, Kyjiv, 1960, No. 2, p. 70. 
During the following century the onomastic formant -enko rapidly spread in all directions from the original home between Kyjiv and Čerkasy. It supplanted the identical patronymic -enok $(<$ en + ok $<$ ŭkŭ), which was "typical for the region of Kyjiv in the middle of the sixteenth century," 6 as the 1552 inventory of a local fortress showed. The 1683 property census ordered by the vojevodas (governors) of Kyjiv revealed that "not a single surname in -enok was recorded" in the area: all such surnames had been automatically changed to -enko.

In contrast, the suffix -enok in the altered form -ënak ( $o>a$ under the influence of akanje, and $e>\ddot{e}$ under stress) became a typically Whiteruthenian (Belorussian) onomastic formant: Vasilënak, 'son of Vasil', Basil'; Kavalënak, 'son of kaval', a blacksmith,' etc.

The suffix -enko has spread to the west as far as the Sluč river and the region of Vynnycja. However, it has not conquered the western part of Ukrainia (Halyčyna and Volyn') where the formants - $u k$, $-j u k,-s^{\prime} k y j,-c^{\prime} k y j,-z^{\prime} k y j$ unquestionably prevailed.

In the seventeenth and eighteenth centuries the surnames in -enko enjoyed a tremendous popularity among the Zaporozhian Kozaks, true patriots and defenders of the country. It became a kind of habit to add -enko to a surname which did not have it. Even representatives of the Kozak elite followed it. For example, Hetman Bohdan Xmel'nyc'kyj's son was "renamed" Xmel'nyčenko by the people. Among the Hetmans of the Zaporozhian Kozaks were Olevčenko (1609), M. Dorošenko (1620's), F. Orendarenko (1630's), V. Tomylenko (1630's), P. Dorošenko (1665-1676), Suxovijenko (1660's), and M. Xanenko (1669-1674). ${ }^{8}$

The percentage of surnames in -enko among Ukrainians was very high in the seventeenth and eighteenth centuries. The 1660 census in the region of Xarkiv (Kharkiv) shows that out of some 2000 names there were 586 surnames in -enko, as Mr. W. Zyla, a graduate student of the University of Manitoba, has recently revealed. The 1770 census of "married Kozaks" in the region of Protovčanske, central Ukrainia, lists 155 persons (fathers and their adult sons only) with

6 O. B. Tkačenko, "Prizvyšča z sufiksom -enko ta sporidneni utvorennja," Ukrajins'ka mova $v$ školi, 1958, No. I, p. 64.

7 Ibid., p. 64.

8 Velyka istorija Ukrajiny by I. Krypjakevyč and others, Winnipeg: Ivan Tyktor Publ. Co., 1948, p. 947. 
surnames in -enko out of the 242 families in the register. ${ }^{9} \mathrm{~A}$ similar census of the pospolytyj or "common" men in the same region at the same time lists 236 surnames in -enko out of a total of 701, i.e., $33.66 \%{ }^{10}$

A high percentage of surnames in -enko remains in present-day Ukrainia, particularly in the southern, central and eastern regions, in spite of the unusually large variety of other onomastic formants: Ju. K. Red'ko has counted over 200 types. ${ }^{11}$ Many Ukrainian poets, writers, literary scholars and other intellectuals of the last 150 years also have surnames in -enko. Among them are Taras Ševčenko, $\mathrm{H}$. Kvitka-Osnovjanenko, O. Storoženko, A. Teslenko, B. Hrinčenko, I. Mykytenko, and L. Kostenko. Out of 747 Ukrainian poets and writers, whose books were published between 1917 and 1957 in Ukrainia, 144 have surnames in -enko, ${ }^{12}$ i.e., every fifth person.

The suffix -enko, which - as was pointed out - is of patronymic origin, plays a considerable role in the formation of surnames. However, family relationship, occupations, personal characteristics, ethnic and place-names, and animal, fish, bird, insect, and other names contribute extensively to Ukrainian onomastic science.

In the survey below we follow the scholarly Slavist transliteration for the spelling of surnames recently introduced in American and Canadian scholarly publications instead of the popular spelling which is generally applied in the English-speaking world. An apostrophe (') is used for the soft sign, and the surnames are stressed according to current usage.

\section{Patronymic surnames}

Andrijénko, son of Andríj, 'Andrew.'

Ivanénko, son of Iván, 'John.'

Kosténko, son of Kost', 'Constantine.'

Mótrenko, son of Mótrja, a mother's name, 'Motrona.'

9 V. O. Holobuc'kyj, Zaporiz'ka Sič v ostanni časy svoho isnuvannja, 1734-1775, Jyjiv: Vydavnyctvo Akademiji Nauk Ukrajins'koji RSR, 1961, p. 216-224.

10 Ibid., p. 226-242.

$11 \mathrm{Ju}$. K. Red'ko, “Osnovni slovotvorči typy sučasnyx ukrajins'kyx prizvyšč u porivnjanni z inšymy slovjans'kymy," Filolohičnyj zbirnyk, Kyjiv: Akademija Nauk Ukrajins'koji RSR, 1958, p. 112.

12 Xudožnja literatura vydana na Ukrajini za 40 rokiv, 1917-1957, I, Xarkiv: Vydavnyctvo knyžkovoji palaty URSR, 1958, index, 431-438. 
Odárčenko, son of Odárka, a mother's name.

Pavlénko, son of Pavló, 'Paul.'

Petrénko, son of Petró, 'Peter.'

Serhijénko, son of Serhij, 'Sergius.'

Tymošénko, son of Tymish, 'Thomas.'

Vasýl'čenko, son of Vasýl'ko, dim, of Vasýl', 'Basil.'

\section{Family relationship surnames}

Babénko < bába, 'grandmother.'

Bratunénko < bratún', dim. of brat, 'brother.'

Didénko < did, 'grandfather.'

Sestryčénko < sestrýcja, dim. of sestrá, 'sister.'

\section{Occupational surnames}

Bondarénko, son of bóndar, 'hooper.'

Djačénko, son of djak, 'cantor.'

Kovalénko, son of kovál', 'blacksmith.'

Kramarénko, son of kramár, 'tradesman.'

Krávčenko, son of kravéc', 'tailor.'

Popénko, son of pip, 'priest.'

Ševcénko, son of švec', 'shoemaker.'

Teslénko, son of téslja, 'carpenter.'

Tkačénko, son of tkač, 'weaver.'

4. Surnames indicating personal characteristics or appearance of a person

Biloúščenko ( $<$ biloús), 'son of a man with a white mustache.'

Hlúščenko ( $<$ hluxýj), 'son of a deaf man.'

Holovátenko (< holová), 'son of a man with a big (wise ?) head.' Hryvénko ( $<$ hrýva, 'mane'), 'son of a man with long thick hair.' Korótčenko (< korótkyj), 'a son of a short man.'

Kosjačénko ( $<$ kósyj), 'son of a squint-eyed man.'

Kryvénko ( $<$ kryvíj ), 'son of a lame man.'

Neumyvájčenko ( $<$ neumyvájko), 'son of one who does not like to wash his face.'

Usénko ( $<$ dial. us, standard vus), 'son of a man with a long mustache.' 
5. Ethnic surnames

Bójčenko, 'son of bójko,' an inhabitant of the uplands in Western Ukrainia.

Lytvynénko, 'son of lytvýn,' 'Lithuanian.'

Nimčenko, 'son of nimec',' 'German.'

Túrčenko, 'son of túrok,' 'Turk.'

Volóščenko, 'son of dial. vólox,' 'Italian' or 'Rumanian.'

\section{Place-names}

Dniprénko $<$ Dnipró, 'Dnieper,' a river.

Myrhoród čenko < Mýrhorod, 'Myrhorod,' a city.

Oxtýrčenko < Oxtýrka, 'Oxtyrka,' a town.

\section{Animal surnames}

Bobrénko $<$ bibr, 'beaver.'

Buhajénko < buháj, 'bull.'

Losénko < los', 'elk.'

Vedmedénko < vedmid', 'bear.'

Vóvčenko < vovk, 'wolf.'

\section{Bird and fish surnames}

Čaplénko < čáplja, 'heron.'

Hórlenko < hórlycja, 'turtle-dove.'

Horobénko < horobéc', 'sparrow.'

Kačurénko < káčur, 'drake.'

Koropénko < kórop, 'carp.'

Lebedénko < lébid', 'swan.'

Vjunénko < vjun, 'river loach.'

9. Insect surnames

Komarénko < komár, 'gnat.'

Žučénko < zuuk, 'beetle, scarab.'

10. Tree, fruit and vegetable surnames

Burjačénko < burják, 'beet.'

Dubénko $<d u b$, 'oak.'

Hrušénko < hrúša, 'pear.' 
11. Surnames derived from adjectives

Bilénko < bílyj, 'white.'

Čornénko < čórnyj, 'black.'

Červonénko < červonyj, 'red.'

Syvénko < sývyj, 'grey-haired.'

Among other popular surnames ending in -enko are those derived from various nouns:

Bidénko < bidá, 'misfortune.'

Harbuzénko < harbúz, 'pumpkin.'

Horbénko < horb, 'hill.'

Krylénko < kryló, 'wing.'

Povsténko < povst', 'thick felt.'

Vozénko < viz, 'cart, wagon.'

Júščenko < jú ška, 'soup.'

Since the suffix -enko is very productive in Ukrainian the possible number of such surnames is limitless.

The surnames listed above were gathered from various sources, mostly from contemporary Ukrainian periodicals published in Ukrainia and abroad. Some of them were heard on broadcasts originating from Kyjiv, the capital of Ukrainia. Therefore none of these surnames are fictitious.

Masculine surnames in -enko are declined in all cases: Nominative - Petrenko, Genitive - Petrenka, Dative - Petrenkovi, Accusative - Petrenka, Instrumental - (z) Petrenkom, Prepositional - (na) Petrenkovi, Vocative - Petrenku! On the other hand, feminine surnames in -enko are as a rule indeclinable.

As examples of the Russianization of the Ukrainian formant -enko, the surnames Kovalénkov and Rylénkov (modern Russia poets), and Konénkov (a Russian sculptor) can be mentioned; their bearers are undoubtedly of Ukrainian origin. The pure Russian suffix $-o v(-e v)$ is a corresponding formant of the Ukrainian -enko $(-j e n k o)$.

University of Alberta 